\title{
REGULATION OF WAGES AND HOURS PRIOR TO I938
}

\author{
FRANK T, DE VYVER*
}

Passage of the federal wage and hour bill did not represent a sharp break with laissez faire in this field. Rather did that law mark a logical step in a movement that, both here and abroad, has been progressing for many years. As a matter of fact the Federal Government has been making attempts to raise the standards for various groups of workers since 1840 . From an economic point of view, federal legislation of this sort differs from state regulation principally in extent of coverage. Any history of wage and hour legislation must, therefore, include the interesting story of state laws.

Before tracing the development of state and federal interferences with the "natural laws" of economics, however, a distinction should be drawn between such interferences on the basis of motivating principles. Such classification is necessary not so much for describing historical development as to clear the air for future discussions lest advocates be striving for one type of law and the opponents be arguing against an entirely different sort. Motives, to be sure, are exceedingly difficult to fathom and undoubtedly reasons given to legislative bodies and courts are not always the actual ones. Furthermore, different interests may sponsor the same bill for unrelated, and, perhaps, inharmonious, reasons.

Classified on the basis of motives, hour legislation may be divided into five groups. In the first place, protection of health has been the underlying reason for a considerable part of American legislation. Certainly the legal reduction of weekly hours from 60 to 50 can be classed in no other way. Somewhere in the demand for a downward trend of hours the notion that unemployment can be cured by having every one work fewer hours has stimulated government action. A 30-hour a week proposal may be thus classified. Between the 30-hour and the 50-hour a week proposals lies the point above which health considerations are paramount and below which curing unemployment is the more important purpose. The third type of hour law envisages an indirect increase in wages. It is not supposed that required work can

- A.B., 1926, M.A., r927, Oberlin College; M.A., 1930, Ph.D., 1935, Princeton University. Assistant Professor of Economics, Duke University, since 1935. Merit Examination Supervisor, North Carolina Unemployment Compensation Commission, since 1938. Research Assistant in Labor Problems at the Institute for Research in Social Sciences, University of Virginia, 1928-1930. Co-author of Labor in the Industrial South (1930) and The Development of Economic Society (1937). Contributor to periodicals on labor problems. 
always be accomplished in the shorter time period; the established hours are the basic hours and extra pay is expected for overtime. In actual practice, depending on the industry, the same law may bring about better health, shared work, or increased pay. A fourth type of regulation, recently introduced in European countries, increases the usual hours of work, for the benefit of a state defense program. Such legislation has not as yet found a counterpart in this country. These four groups of hour laws affect private industry. Organized labor has likewise sought and gained special concessions from governments for work on government projects. Improved standards under such circumstances are easier to obtain by law than by collective bargaining. There is a desire here to take advantage of a relatively strong, strategic position, coupled with the desire that governmental projects shall set examples of good standards and not depress labor conditions in any degree.

Five distinct motives can likewise be found for wage regulations. The historic reason for such legislation has been to improve the lot of the lowest-paid fringe of female workers, unable because of lack of bargaining strength to help themselves. This motive is still an important one, but a different principle underlies fixing wages by law considerably above the average wages of the industry. Such legislation is based upon the so-called purchasing power theory of the business cycle. Between these first two types it is not always easy to distinguish. Whereas a 20-cent minimum is certainly directed to the mitigation of the sweating evil, opinion might differ as to the reason for a 50-cent minimum. Another type of wage-fixing has been motivated by the belief that modern economic society must be planned rather than be allowed to run its supposedly unplanned course. Wage-fixing under such a scheme becomes merely one aspect of general price-fixing. A fourth type of law has been designed to eliminate industrial warfare by establishing boards to arbitrate disputes, incidentally to fix wages. Finally, as with hour legislation, labor and its friends have sought for reasons indicated there to obtain good wages in government sponsored work by legislation rather than struggle for those wages by means of collective bargaining. Laws of the three latter types go further than merely fixing a minimum wage. They provide for the establishment of the entire range of rates including the differentials as well as the minima.

This paper will deal with the various types of laws but no attempt will be made to classify each legislative enactment that is mentioned.

\section{Hours}

The present fair standards law provides both hour and wage regulation. Historically, however, these two phases of the employment contract have been acted upon separately.

Hour legislation has been the generally accepted state practice for many years. In I898 the Supreme Court approved a Utah law, regulating the hours of labor for men working in mines. In that same decision was laid the foundation for future hour laws when Mr. Justice Brown, speaking for the Court, said in part:" "But the fact that

${ }^{1}$ Holden v. Hardy, 169 U. S. 366,397 (1898). 
both parties are of full age and competent to contract does not necessarily deprive the State of the power to interfere where the parties do not stand upon an equality or where the public health demands that one party to a contract shall be protected against himself." This judgment had the apparent effect of overruling an earlier state court decision with respect to an Illinois maximum hours law for women. ${ }^{2}$

Subsequent decisions of the Supreme Court, ${ }^{3}$ with the exception of the refusal to uphold a New York ro-hour law for male bakery workers, ${ }^{4}$ paved the way for nation-wide acceptance of maximum hour laws for women and in some instances for men. By January I, I939, 44 states had limited to some degree the hours of labor for women, and five states likewise included men in the general laws. About a dozen states, furthermore, limit hours for men in specific industries.

Though hour regulation has been chiefly reserved to the states, the Federal Government has not ignored that half of the labor contract. Until recently, however, federal activities have been limited to public works and to the transportation industry. In the former, the Government merely acts as an employer in establishing working conditions. In the latter, the way for such laws is made easier by the more ready solution of constitutional problems and the fact that the safety of the traveling public is involved.

Though acting in the role of employer, the Government in fixing hours has had considerable influence upon other industries. Since 1840 when President Van Buren by executive order stipulated the ro-hour day in Government navy yards, ${ }^{5}$ the Federal Government has led industry in hour reduction. As early as I868, when the 8-hour day was little more than a fantastic dream, Congress decreed those hours for any workers employed on Government contracts. ${ }^{6}$ That law, though not entirely effective, was continued and by 1936 further Congressional action had provided regulation to cover most possible cases. The Walsh-Healey Act, to be discussed later, was passed in that year.

Excessive hours having been recognized as a factor in railroad accidents, both state and federal legislation was passed to change the situation. In 1907, by a law applicable to workers on interstate railroads, Congress set $I 6$ as the maximum number of hours to be worked in one day and provided for adequate rest periods. ${ }^{7}$ In I9I6, at the insistence of President Wilson who sought to avert a strike, Congress provided for a basic 8-hour day for railroad trainmen with no reduction in wages. ${ }^{8}$ This latter feature seemed to prove to those opposing the act that it was in reality a method of increasing wages rather than reducing hours.

By the time of the New Deal, regulation of hours by government was a principle

2 Ritchie v. People, 155 Ill. 98, 40 N. E. 454 (1895).

Muller v. Oregon, 208 U. S. 412 (1908); Miller v. Wilson, 236 U. S. 373 (1915); Bunting v. Oregon, 243 U. S. 246 (I9r7).

' Lochner v. New York, 198 U. S. 45 (1905).

- 8 Commons, Documentary History of Axierican Industrial Society (1910) 85, as referred to in Commons and Andrews, Princtples of Labor Legistation (4th ed. 1936) 117.

i6 STrt. 77 (1868); see Commons and ANDREws, op. cit. supra note 5, at iI8.

34 Star. 1415 (1907), 45 U. S. C. 561 (1935).

- 39 STAт. 72I (19r6), 45 U. S. C. $\$ 65$ (1935). 
accepted in general by legislatures and courts alike. Most states had accepted rohour laws for women and were considering regulations providing for shorter times for both men and women. ${ }^{9}$ The federal government had likewise regulated in those fields open to it. Other state and federal laws can best be considered in a discussion of wage legislation.

\section{WAGES}

State supervision of wages has had an entirely different legislative history than that of hour legislation. Advocates of nineteenth century economic liberalism were apparently able to convince state legislatures or, in any event, the courts that any tampering with the wage side of the employment contract would surely lead to widespread unemployment among those for whose benefit the law was passed. Yet throughout the world a study of actual conditions proved that however horrible a situation might be brought about by interference with economic laws, the workers could hardly be any the worse off.

The first tempting of the divine hand of competition came in Australia. Despite the newness of the country and the comparative scarcity of the labor factor, the economic position of a large number of the working population shocked the legislature of the country into action. In 1896 , after a series of studies had been made of the situation, a minimum wage law went into effect in Victoria.

The skies did not fall in Victoria and England likewise decided to tempt fate. A vigorous campaign, however, preceded legislative action. The London Daily News, a leading newspaper, arranged an exhibit to illustrate the evils of sweating. In a large hall typical rooms were set up, and typical workers made lace, chains, and many other commodities for the wages conspicuously posted by each booth. Such a display accomplished more than pages of statistics. In Ig09 Parliament provided for the establishment of wage boards for industries with exceptionally low wage scales. Selected for the first application of the law were paper box making, chain making, lace making by machinery and wholesale ready-made tailoring.

Since the passage of the first regulations, the history of wage legislation in Australia and in England has been the story of improvement. ${ }^{10}$ Gradually in Australia hours and wages have become matters for direct or indirect state action not only to better conditions in the sweated industries but also to settle trade disputes between employers and employees by means of compulsory arbitration. In Great Britain, over 50 boards now determine minimum wages for the industries concerned

\footnotetext{
${ }^{9}$ However, on March 14 of this year, in passing judgment on a statute making 56 hours the maximum in the manufacturing and mercantile establishments of South Carolina, the supreme court of that state said in part, "the Court must conclude that the Act violates the due process, equal protection and contract clauses of both State and Federal Constitutions, in that it is not a proper exercise of the police power of the State." Gasque, Inc. v. Nates, 2 S. E. (2d) 36.

Pennsylvania's maximum hour law applying to men as well as to women was held unconstitutional by the state supreme court on the grounds of improper delegation of legislative power. Holgate Bros. Co. v. Bashore, 33 I Pa. 255, 200 A. 672 (1938).

${ }^{10}$ See Armstrong, Insuring the Essentials (1932) and Millis and Montgomery, Labor's Progress and Some Basic Labor Problems (1938) for detailed discussion of the Australian and English minimum wage movements.
} 
and, imperfect though the present situation is, the intense suffering of pre-interference days has been ameliorated.

State regulation of wages in the United States may be divided into three periods. First came the period of investigation of conditions and experimentation with laws which culminated in 1923 at the time the Supreme Court in deciding the case of Adkins v. Children's Hospital ${ }^{11}$ invalidated the District of Columbia legislation. This decision was followed by another type of legislation designed to meet judicial objections but it, too, was finally declared illegal in 1936 by the Tipaldo decision declaring the New York law unconstitutional. ${ }^{12}$ Finally, the way for further legislation was opened when the Court in 1937 upheld the Washington law in West Coast Hotel Company v. Parrish. ${ }^{13}$

Massachusetts passed the first minimum wage law in I912. This action culminated more than a decade of activity on the part of the National Consumers' League. That organization, tracing its ancestry to the Consumers' League of the City of New York, had worked for many years in an attempt to obtain voluntary cooperation for a $\$ 6$ a week minimum wage. Competitive conditions were such that these efforts came practically to naught with the result that after Ig09 the League devoted itself to legislative efforts rather than to voluntary white lists.

The Massachusetts law provided for a wage commission with authority to establish wage boards as needed. These industry boards, after studying all the factors involved, were charged with determining the minimum rate for the particular industry. The rate thus arrived at, however, was not mandatory. Failure to comply with a board ruling merely involved the employer in publicity when the board published its rulings together with the statement of noncompliance.

Other legislatures followed the Bay State's lead and i4 additional states, Puerto Rico and the District of Columbia had enacted some type of law by $1923 .^{14}$ Much of this legislation was far from satisfactory. Massachusetts and Nebraska laws were not mandatory and, as the Commissioner in Massachusetts said in IgI6, the sweat shops against whom the legislation was directed were operated by the type of employer who would pay no attention to an advisory minimum. Four of the laws (Utah, Arizona, South Dakota, and Puerto Rico) established a legislative minimum instead of leaving the actual rate for determination by a board. Such a plan is hopeless in a state with diversified interests and during a period of rapid price changes. Two of the laws (Colorado and Nebraska) never went into effect. The record for the decade had certainly not been spectacular. All of the legislation except Massachusetts' non-mandatory law was in states predominantly agricultural. Yet a start had been made and the people had had a chance to see that sweat-shop wages could be raised without entirely upsetting the entire economy.

${ }^{12} 26$ I U. S. 525 (1923).

${ }^{13}$ Morehead v. People ex rel. Tipaldo, 298 U. S. 587.

13300 U. S. 379.

${ }_{16}$ Wisconsin, Minnesota, Oregon, Washington, California, Utah, Colorado, and Nebraska all enacted laws in 1913; Kansas and Arkansas added the legislation in 1915; Arizona passed a law in I917, and the District of Columbia, Puerto Rico, North Dakota, and Texas in 1919, and South Dakota in 1923. 
Probably one reason for the slow progress of wage laws was the position of organized labor. Samuel Gompers sought to make the American Federation of Labor an economic rather than a political group. "We want a minimum wage established," he wrote in 1913 , "but we want it established by the solidarity of the working men themselves through the economic forces of their trade unions rather than by any legal enactment."15 Labor, however, has always favored regulations which "affect or govern the employment of women and minors, health and morals, and employment by federal, state, or municipal government." 16 This plan of legislating for the economically weak is apparently still the official policy of the Federation..$^{17}$

Industrial unions, however, are probably more interested in raising standards by legislation than the craft affiliates of the American Federation of Labor. The $193^{8}$ United Mine Workers Convention, for example, resolved that the national officers should submit proposed legislation to Congress, "establishing as the law of the land a six-hour day and a thirty-hour week for all industries in interstate commerce without any decrease in the established wages and a guaranteed minimum wage. ${ }^{18}$

All of the early laws, i.e., those passed before $x 923$, provided that the minimum wage established by a board should be adequate to supply women with necessary costs of living and to maintain them in health and welfare. The District of Columbia law, and some others, likewise provided that the wage should be high enough to protect morals. That state maintenance of such a standard constituted the proper use of the police power had been challenged, of course. In the case of Stettler $v$. O'Hara (1914), ${ }^{19}$ the state supreme court had upheld the Oregon law. By April, I9I7, the Supreme Court, by a four to four decision, had sustained the verdict of the state court. ${ }^{20} \mathrm{Mr}$. Justice Brandeis, only recently appointed to the Court, took no part in the case since he had helped prepare the brief for the state.

Such was the apparently settled constitutional status of state wage laws for women when in 1923 the Supreme Court rendered its decision concerning the minimum wage law of the District of Columbia. ${ }^{21}$ Both Mr. Justice Sutherland's opinion for the majority and the rigorous dissents of Mr. Justice Holmes and Chief Justice Taft, have become classics to be quoted in part by all advocates of advanced social legislation.

This is not the place, however, to discuss this decision and these dissents in detail. ${ }^{22}$. Justice Sutherland failed to see a reasonable connection between public health, safety, and morals and the regulation of wages. Presumably the justice believed that individual wages are without exception determined by the value of the service rendered. If these women contracted with their employers to receive low wages, the inconvertible conclusion was that they were receiving all they were worth. Govern-

\footnotetext{
${ }^{15} 49$ INT. Molders J., April, I913; cf. Shishkin, Wage-Hour Law Administration from Labor's View. point (I939) 29 AM. LAB. Legis. Rev. 63, 64. ${ }^{16} 5$ I INT. Molders J., Feb., I915.

17 See AFL Proceedings (1933) 279, (1934) 357, (1935) 451.

18 (I938) 49 UNited MiNe Workers J., No. 4, p. 1 I.

10 69 Ore. 5r9, 193 Pac. 743.

${ }^{2}$ Adkins v. Children's Hospital, supra note II.

${ }^{22}$ See Powell, The Judiciality of Minimum Wage Legislation (r924) 37 Harv. L. Rev. 545.
} 
ment regulation by interfering with freedom of contract and exacting "from the employer an arbitrary payment" was taking property without due process of law and therefore against the due process clause of the Fifth Amendment.

Persons interested in advancing social legislation thought they had discovered a possible way out in a dictum of Justice Sutherland, which seemed to imply that whereas increasing wages to protect a woman's health and morals was not a subject for legislative action, a legislature could raise a low wage to a point high enough to cover the value of the service. ${ }^{23}$ In drafting new laws, therefore, it was provided that in addition to considering need, wage boards should establish rates "commensurate with value of service or class of service rendered." In I924 Wisconsin took the lead in the attempt to meet the Court's objections, but it required the conditions accompanying the depression starting in I929 to help carry additional laws through the legislatures. This second wave of legislation brought seven new laws in I933 and in 1934 a mandatory feature to the old non-mandatory Massachusetts law. All of these laws contained the "value of service" clause designed to overcome the Supreme Court's objections. It is noteworthy, moreover, that whereas all the early laws were passed in agricultural states, the r933 group included New York, New Jersey, Ohio, Connecticut, and Illinois as well as New Hampshire and Utah.

When in 1936 the Supreme Court by a five to four decision invalidated the New York State law, students of social legislation were greatly surprised that legal opinion on this subject had remained stationary for thirteen years. ${ }^{24}$ The Court refused to distinguish between the "living wage" law invalidated in the Adkins case and the "living wage plus value of service" law of New York State and others. The Court refused to distinguish, but the following year when asked by the State of Washington to change its mind, the same court personnel did so, saying in West Coast Hotel Co. v. Parrish" that "the case of Adkins v. Children's Hospital should be, and it is overruled." Mr. Justice Sutherland, who had written the earlier decision, and three of his colleagues dissented.

Pennsylvania, Nevada, and Oklahoma have passed wage laws since the Parrish decision. This brings the total of state laws to 25 and the District of Columbia and Puerto Rico likewise have legislated. Only Oklahoma has brought men within the law; ${ }^{26}$ the other states abiding by tried legislative and constitutional standards have included only women and minors.

Always a powerful argument against state social legislation has been that of interstate competition. Since the days of the earliest factory legislation to the present,

${ }^{23} \mathrm{Mr}$. Justice Sutherland after condemning the District of Columbia law for exacting an arbitrary payment "with no causal connection with . . . the contract or the work the employee engages to do," continued with these words: "The moral requirement implicit in every contract of employment, viz., that the amount to be paid and the service to be rendered shall bear to each other some relation of just equivalence, is completely ignored." $26 \mathrm{r}$ U. S. $525,558$.

${ }^{34}$ Morehead v. People ex rel. Tipaldo, supra note $12 . \quad{ }^{25}$ Supra note 13.

${ }^{30}$ The supreme court of the state has recently declared the Oklahoma law unconstitutional in so far as it affects men and minors by reason of insufficiency of title. On other grounds the court said the law met constitutional tests. Associated Industries of Okla. v. Industrial Welfare Commission, 90 P. (2d) 899 (1939). 
each new proposal for reform has been greeted with the cries that it would drive industry from the state or nation. Real or imagined, this factor has had to be met. Usually the way around has been by means of federal legislation such as the present social insurance laws. Another method tried in fixing wages and hours has been interstate pacts.

This movement for cooperative action in the field of wages and hours was instigated by Governor Roosevelt of New York at a meeting of the governors in Albany in I93I. Later conferences culminated in May, I934, when representatives from seven states (Connecticut, Maine, Massachusetts, New Hampshire, New York, Pennsylvania, and Rhode Island) signed the first interstate compact. The pact aimed to secure uniformity of standards for conditions of employment, particularly with reference to wages and hours of women. The New York law incorporating the aforementioned "value-of-service" principle was taken as the standard. According to the terms of the compact, it was to become operative as soon as two states had ratified it and the consent of Congress had been obtained. By $193^{8}$ three states had ratified: Massachusetts, New Hampshire, Rhode Island, and Congress had given the necessary approval. ${ }^{27}$

The quicker method of obtaining uniform results among states whose industries compete is by means of federal legislation. In this field the spectre of states rights has always been a restraining influence. Nevertheless the present wage and hour bill does not mark the first move of the federal government into this type of legislation. At least until the Fair Labor Standards Act of 1938 , however, federal legislation had been based on different principles than those embodied in state laws. State laws have attempted to mitigate the sweating evil among women and minors admittedly economically weak; federal legislation has involved either an attempt to aid weak bargainers or to legislate for the "purchasing power" theory of business cycles, or the spending theory of recovery. Occasionally these two motives have likewise involved the clearing up of a sweated industry.

Reference has previously been made to the Adamson law passed in Igr6 to avert a railroad strike. The Brotherhoods were prepared to enforce their demands by striking and the railroads were apparently prepared to stand pat. The law, ${ }^{28}$ called an 8-hour law, provided for a basic 8-hour day but likewise provided that no reduction could be made in wages until an investigating committee established by the act had reported. In this way the federal government apparently strengthened the bargaining power of the union. The Adamson Act was certainly not designed to improve conditions in a sweated industry.

The principles involved in wage rate determination under NRA codes are not readily determined. Presumably the codes were aimed at establishing a wage floor above the level to which wages had fallen during the depression. In many instances this was true but in others the obvious reason was not so much to cure the evils of a 
sweated industry made worse by depression but to fix a wage at the point the workers felt was a reasonable return for their services.

All of the 585 "codes of fair competition" contained definite minimum wage and maximum hour provisions. The wage minima ranged from $121 / 2$ cents an hour for the Puerto Rico needle trades to 70 cents in the construction industry codes. In codes covering 55 per cent of all the codified employees the rate was 40 cents or over; about five per cent of the codified workers were guaranteed minima less than 30 cents. ${ }^{29}$

Apparently if the Supreme Court had not acted unfavorably on the N.I.R.A., ${ }^{30}$ this attempt at federal regulation of wages would have resulted in two things. In many industries sweatshop conditions would have been ameliorated; in others actual wage-fixing on a scale not heretofore attempted would have resulted.

General minimum wage legislation having been returned to the states by the action of the Supreme Court, the Federal Government attempted to fix certain standards in those circumstances undoubtedly in its field of control. None of these wage clauses, with the possible exception of those contained in the Sugar Act of I937, are designed to raise the standards of sweated workers. They belong more with that type of legislation designed to insure to workers upon public projects the prevailing wage in the community or industry.

The United States Housing Act of $1937{ }^{31}$ for example, includes a section that all contracts "shall contain a provision requiring that the wages or fees prevailing in the locality, as determined, or adopted . . . by the Authority, shall be paid to all . . . laborers and mechanics employed in the development or administration of the lowrent housing or slum-clearance project involved." Similarly the Davis-Bacon Act with respect to public works contains a proviso that all contracts must contain a wage clause for wages at rates which the Secretary of Labor has found to be prevailing. ${ }^{32}$

Of more wide-spread application is the Walsh-Healey $\mathrm{Act}^{33}$ of 1936 applying to all large federal contracts for the purchase of commodities. In addition to the 8-hour day and 40-hour week, the law provides that the Secretary of Labor shall fix minimum wages at the prevailing minimum wages for persons employed on similar work in the locality. Thus far the Secretary has fixed minima ranging from $32 \frac{1}{2}$ cents an hour for the manufacture of men's underwear in certain parts of the South to $671 / 2$ cents an hour in the men's hat industry. ${ }^{34}$ Because the administrator is limited to fixing the prevailing wages, theoretically the Act should have little effect upon wage rates. Actually future studies may show that administrative discretion has served to boost the wage rates at least on the sweated fringe of the multitude of industries from whom the Federal Government purchases.

${ }^{20}$ (I935) 43 Mo. Lab. Rev. 886.

${ }^{30}$ Schechter Corp. v. United States, 295 U. S. 495 (1935).

32 50 STAT. 896,42 U. S. C. §I 4 I6 (2) (Supp. 1938).

32 46 Stat. Y 494 (I93I), 40 U. S. C. \$276a (I935) as amended by 49 Stat. IOII (I935), 40 U. S. C. $\$ 276 \mathrm{a}$ (Supp. 1938).

${ }^{33} 49$ STAT. 2036 (1936), 4 I U. S. C. $\$ 35$ (Supp. 1938).

34 (I937) 45 Mo. LaB. Rev. 694. 
Three other New Deal laws contain provisions giving the Federal Government control of certain wage rates. Most likely to affect an unorganized, poorly paid group of workers is the Sugar Act of $1937^{35}$ Designed to aid sugar producers, the act none the less contains a clause forbidding benefit payments unless the producer "shall have paid wages therefore at rates not less than those that may be determined by the Secretary to be fair and reasonable after investigation and due notice and opportunity for a public hearing. ..."

Likewise giving a federal agency the power to fix wages are the labor clauses of the amended Merchant Marine Act of $19366^{36}$ and the Civil Aeronautics Act of 1938. The former provides that the United States Maritime Commission shall determine working rules for all types of vessels receiving an operating differential subsidy. The latter enacts into law a I934 decision of the old National Labor Board which set a gradually increasing base rate of $\$ 1600$ as annual wages and hourly rates at $\$ 4$ an hour and up for all air line pilots.

From the early Utah law regulating hours of labor in the mines of the state, and the Massachusetts non-mandatory wage law, to the present labor standard laws of a state like New York has marked a real change in legislative feeling toward state interference in the labor contract. The federal interference in the field from the early days of President Van Buren's first decree to the days of the NRA and thence to the present wage-hour law has likewise seemed spectacular. Only a study of the intervening years indicates how gradually public opinion in general has shifted from laissez faire to collective action, and how organized labor, in the days of Gompers so opposed to state interference, has come to accept wage-fixing schemes such as the NRA as part of the economic scene.

\footnotetext{
${ }^{35} 50$ STAT. 903, 7 U. S. C. \$113I (Supp. 1938).

${ }_{58}^{32}$ STAT. 954 (1938), 46 U. S. C. \$113I (Supp. 1938).

${ }^{87} 52$ STAT. 987 (1938), 49 U. S. C. $\$ 48$ I (1) (Supp. 1938).
} 